\title{
SIFAT MEKANIK PAPAN KOMPOSIT BERBAHAN DASAR SERAT SABUT KELAPA DAN SERAT BATANG PISANG
}

\author{
Kosim, Wahyudi, Susilawati dan Aris Doyan \\ Program Studi Pendidikan Fisika \\ FKIP, Universitas Mataram \\ Jalan Majapahit No. 62, Mataram \\ E-mail: kosim.unram@gmail.com
}

\begin{abstract}
Research on the manufacture of composite particle board based on natural fiber: coconut fiber (SSK) and banana fiber (SBP) by using PVAc matrix has been conducted. The purpose of this research is to get the physical and mechanical value of standard on composite board based on SNI03-2105-2006The research method is by taking the comparison of banana fiber reinforcing material (SBP) and coco fiber (SSK) in the form of particle size with composition ie (a) SBP 0\%: SKK 100\% (b) SBP 50\%: SKK 50\%, (c) SBP 80\%: SSK 20, (d) SBP 60\%: SSK 40\%, (e) SBP 40\%: SSK 60\%, (f) SBP 20\%: SKK 80\%, and (g) SBP 100\%: SSK $0 \%$.All composite boards consist of $70 \%$ Matrix and $30 \%$ fiber. The result of physical properties for density ( $\rho$ ) ranges from $0.54 \mathrm{gr} / \mathrm{cm} 3-0.75 \mathrm{gr} / \mathrm{cm} 3$ and for water content $(\mathrm{KA})$ ranges from $10.5 \%-13.9 \%$.As for the mechanical properties of the value of modulus rupture (MOR) ranged between $3483.44 \mathrm{kgf} / \mathrm{cm} 2-7472,30$ $\mathrm{kgf} / \mathrm{cm}^{2}$ and elastic modulus value (MOE) ranged between $15981.23 \mathrm{kgf} / \mathrm{cm} 2-27243,74 \mathrm{kgf} / \mathrm{cm}^{2}$. Based on the analysis of tredline graphs, both for physical and mechanical properties, it turns out for each composition of natural fibers to give different values.This means that the composition of the SSK-SBP mixture has an influence on the physical properties as well as the mechanical properties of the composite board. The quality of natural fiber-based composite board (SSK and SBP) both physical and mechanical properties have been in accordance with the standard reference SNI 03-02105-2006.
\end{abstract}

Keywords : composite particle board, coconut fiber, banana fiber

\section{PENDAHULUAN}

Penelitian mengenai pembuatan papan komposit dari berbagai bahan dasar serat alami telah banyak dilakukan. Papan komposit yang berbahan dasar tunggal dari serat batang pisang telah diteliti oleh Nurrani, L. (2012); Nasmi, H et al. (2011); Noni, N. (2013) yang menunjukkan bahwa papan komposit pisang dapat diproduksi Papan komposit yang berbahan dasar tunggal serat sabut kelapa telah diteliti diantaranya oleh Sudarsono, et al. (2010); Kurniawan,E.(2011); Budha, et al. (2011); Ezema, L.C, at al. (2012); Oroh, et al. (2013) bahwa serabut kelapa berpotensi untuk dapat diproduksi sebagai papan komposit.

Pengembangan penelitian papan komposit berbahan dasar serat alam diantaranya merupakan solusi untuk mengatasi kelangkaan dan mahalnya harga kayu. Walaupun demikian penelitian pembuatan papan komposit berbahan dasar serat alam tergantung keperluan akhir yang ingin dicapai dalam tujuan penelitian. Dalam hal ini peneliti bertujuan untuk membuat papan komposit berbahan dasar serat alam yang beracuan pada Tabel 1 (Rangkuti, 2011).

Tabel 1. Acuan Papan Komposit serat alam

\begin{tabular}{|c|l|l|}
\hline No & $\begin{array}{l}\text { Sifat Fisik dan Mekanik } \\
\text { papan komposit }\end{array}$ & $\begin{array}{l}\text { SNI 03- } \\
02105-2006\end{array}$ \\
\hline 1. & Kerapatan $\left(\mathrm{gr} / \mathrm{cm}^{3}\right)$ & $0,5-0,9$ \\
\hline 2. & Kadar air (\%) & $<14$ \\
\hline 3. & Pengembangan Tebal (\%) & Maks 12 \\
\hline 4. & MOR $\left(\mathrm{kgf} / \mathrm{cm}^{2}\right)$ & Min 80 \\
\hline 5. & MOE $\left(\mathrm{kgf} / \mathrm{cm}^{2}\right)$ & Min 15000 \\
\hline 6. & Kuat rekat internal (IB) & Min 1,5 \\
\hline 7. & Kuat Impak $\left(\mathrm{kgf} / \mathrm{cm}^{2}\right)$ & Min 30 \\
\hline
\end{tabular}

Adapun karakteristik yang ingin dicari adalah untuk mengetahui apakah komposisi campuran serat alam batang pisang (SBP) dan serat alam sabut kelapa (SSK) dengan matriks Poly Vinyl Acetate (PVAc) berpengaruh terhadap sifat fisik dan mekanik papan partikel 
komposit? Serta Apakah papan partikel komposit berbahan dasar serat alam SBP dan SKK dengan matriks Poly Vinyl Acetate (PVAc) memnuhi standar SNI03-2105-2006?

\section{LANDASAN TEORI}

Penelitian mengenai sifat mekanik papan komposit berbahan dasar serat alam, pada prinsipnya membuat produk papan berbahan dasar serat alam (serat sabut kelapa $=\mathrm{SSK}$, dan serat batang pisang $=\mathrm{SBP}$ ). Serat tersebut sebelum dibuat dalam pencetakan papan, maka bahan dasarnya serabut dipotong-potong kecil $\pm 1 \mathrm{~cm}$, kemudian di blender, sehingga ketika dicetak dihasilkan papan partikel komposit. Ukuran ini bertujuan agar material serat ketika dicampur antara SSK dan SBK lebih homogen sebelum keduanya diaduk bersama matrik lem PVAc. Perbandingan massa serat dan massa matrik adalah 30\%:70\%. Ukuran perbandingan ini dilakukan berbasarkan telusur literatur, yang mengungkapkan bahwa massa matriks lebih besar dari massa serat menghasilkan nilai uji kuat tarik dan kuat lentur terbaik untuk suatu papan komposit (Kurniawan, 2011).

Adapun alasan serat batang pisang dan serat sabut kelapa yang digunakan dalam penelitian ini adalah adanya kesamaan unsur yang terkandung, seperti lignin, selulosa dan hemiselulosa. Lignin merupakan senyawa yang melekatkan satu serat dengan serat yang lainnya. Oleh karena itu untuk mempermudah melepaskan lignin maka serat tersebut di rendam terlebih dulu kurang lebih 24 jam dalam larutan $\mathrm{NAOH}$ 0,5\%. Hakim \& Febrianto (2005) telah mendapatkan hasil yang memuaskan dengan mendapatkan serat melalui perendaman pelepah batang pisang dengan air yang dicampur larutan $\mathrm{NaOH}$. Selain itu dampak hasil pernedaman serat SSK maupun SBP, serat menjadi berwarna kekuningan dan tidak kaku walaupun dalam keadaan kering (Khotimah, 2014). Selanjutnya serat tersebut dipotong-potong, hasilnya dapat dilihat pada Gambar 1 berikut ini.

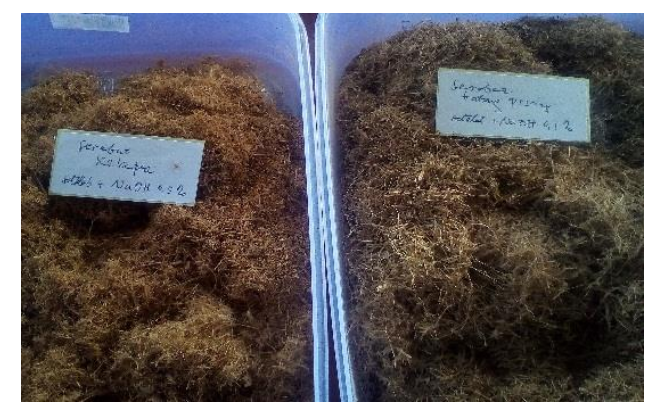

Gambar 1. Serat SSK dan SBP

Penggunaan Polivinil asetat (PVAc) atau disebut juga lem putih dengan formula $\left(\mathrm{C}_{4} \mathrm{H}_{6} \mathrm{O}_{2}\right)_{n}$ adalah sebagai matriks atau perekat serat. PVAc banyak digunakan sebagai lem kayu, kertas, bahkan digunakan dengan campuran semen putih sebagai blanmir untuk meratakan tembok beton. PVAc merupakan polimerisasi adisi terinisiasi radikal bebas dimana suatu monomer atau campuran monomer dipolimerisasikan di dalam air denganperubahan surfaktan untuk membentuk suatu produk polimeremulsi yang bisa disebut lateks. Artinya kekentalan lem PVAc masih bisa diencerkan dengan menggunakan air.

Papan partikel berbahan serat alam SSK dan SBP ini di rekat dengan menggunakan lem PVAc, dimana dalam pencetakannya diberikan gaya yang merata dan kemudian di jemur di bawah terik matahari atau di oven. Berdasarkan sifat fisiknya, jelas hasilnya berupa papan buatan yang tersusun dari serat alam sabut kelapa dan juga serat batang pisang. Papan tersebut mempunyai ciri massa jenis juga kadar air. Sedangkan sifat mekaniknya diteliti masalah kekuatan tarik atau putusnya bahan dengan diberikannya persamaan MOR(modulus of Rupture) dan kuat lentur dengan persamaan MOE (modulus of elastics).

Pengujian massa jenis pada papan partike komposit dilakukan pada kondisi kering udara dan volume kering udara. Sampel papan partikel komposit ditimbang untuk mengukur massanya $(\mathrm{m})$, lalu diukur rata-rata panjang, 
lebar dan tebalnya untuk menentukan volumenya $(V)$. Massa janis $(\rho)$ sampel papan partikel komposit dihitung dengan persamaan:

$$
\rho=\frac{m}{V}
$$

Hasil pengukuram kerapatan ditulis

$$
\rho^{\prime}=\rho \pm \Delta \rho
$$

Dimana standar deviasinya dihitung dengan menurunkan dari persamaa (1) adalah

$$
\Delta \rho=\frac{1}{V} \Delta m-\frac{m}{V^{2}} \Delta V
$$

Sedangkan untuk sifat fisik Kadar air , dimana terdapat perbedaan massa papan saat basah $\left(m_{1}\right)$ kemudian di keringkan (dioven) dan setelahnya ditimbang kembali dengan mendapatkan massa saat kering $\left(m_{2}\right)$ ), sehingga rumusnya untuk kadar air (KA) diturunkan sebagai berikut,

$$
K A=\frac{m_{1}-m_{2}}{m_{2}} \times 100 \%
$$

Pengujian terhadap sifat mekanik papan partikel komposit untuk uji kuat tarik dan kuat lentur, sampel papan partikel komposit tersebut akan dikenai stress $\sigma$ ( tegangan gaya luar) dan akibatnya terjadi straine (peregangan) pada sampel papan tersebut. Secara teori menurut persamaan elastis modulus Young (Y) dituliskan dengan persmaan

$$
Y=\frac{\sigma}{\varepsilon}
$$

Secara teknik pengukuran uji mekanik dengan menggunakan UTM merek AnD, model RTG 1310 dan bentuk sampel yang hendak diukur, maka pengukuran terhadap nilai MOR (modulus Rupture denga uji tarik memenuhi persamaan

$$
M O R=\frac{3 P L}{2 l h^{2}}
$$

\section{Dimana,}

MOR : modulus rupture kuat patah $\left(\mathrm{kgf} / \mathrm{cm}^{2}\right)$

$$
\begin{array}{ll}
P & : \text { bebanpatah }(\mathrm{kgf}) \\
L & : \text { jarakpemegang spesimen }(\text { jaws })(\mathrm{cm}) \\
h & : \text { tebal spesimen }(\mathrm{cm})
\end{array}
$$

$l \quad:$ lebar spesimen $(\mathrm{cm})$

Hasil Pengukuran dituliskan:

$$
\mathrm{MOR}^{\prime}=M O R \pm \triangle M O R
$$

Dimana standar deviasi MOR didapat dari penurunan rumus (6) adalah

$$
\Delta M O R=\frac{3 L}{2 l h^{2}} \Delta P+\frac{3 P}{2 l h^{2}} \Delta L-\frac{3 P L}{2 l^{2} h^{2}} \Delta l-\frac{6 P L}{2 l h^{3}} \Delta h
$$

Penjelasan teori uji tarik bentuk sampel dan besar gaya luar dapat digambarkan sebagai berikut (Azhari, 2008).

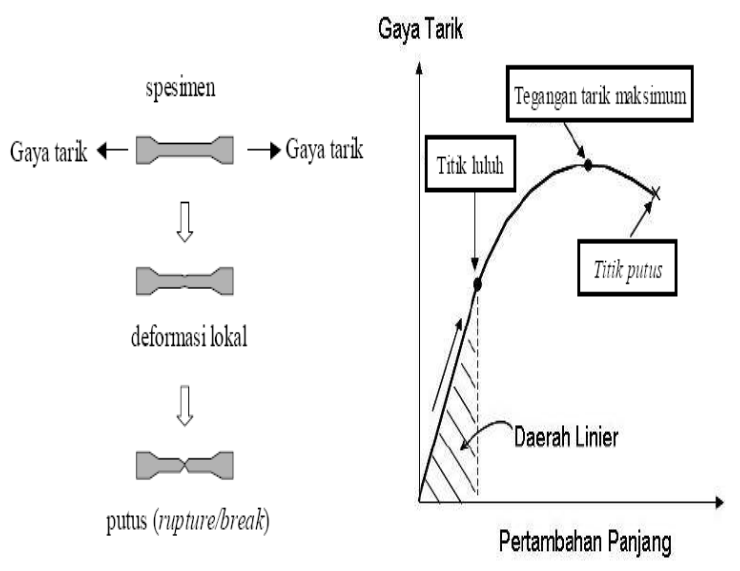

Gambar 3. Spesimen uji tarik dan gaya luar

Sedangkan untuk pengukuran uji lentur (Bending test) sebagai MOE, persamaan berlaku:

$$
M O E=\frac{P L^{3}}{4 y l h^{3}}
$$

Dimana,

$$
\begin{array}{ll}
M O E & : \text { Modulus of Elasticity }\left(\mathrm{kgf} / \mathrm{cm}^{2}\right) \\
P & : \text { berat beban maksimum }(\mathrm{kgf}) \\
L & : \text { jarak sangga atau span }(\mathrm{cm}) \\
y & : \text { kelengkungan pada batas beban } \\
& \text { proporsional (jarak defleksi) }(\mathrm{cm}) \\
h & : \text { tebal spesimen }(\mathrm{cm}) \\
l & : \text { lebar spesimen }(\mathrm{cm})
\end{array}
$$

Hasil pengukuran ditulis

$$
\mathrm{MOE}^{\prime}=\operatorname{MOE} \pm \triangle M O E
$$

dimana

$$
\Delta M O E=\frac{L^{3}}{4 y l h^{3}} \Delta P+\frac{2 P}{4 y l h^{3}} \Delta L-\frac{2 P L^{3}}{4 y^{2} l h^{3}} \Delta y \ldots \ldots
$$




$$
-\frac{2 P L^{3}}{4 y l^{2} h^{3}} \Delta l-\frac{2 P L}{4 y l h^{4}} \Delta h
$$

Aktivitas pengukuran sampel dapat dilihat pada Gambar 3 berikut ini (Multazam, 2014).

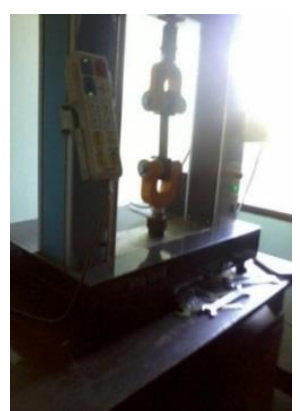

(a)

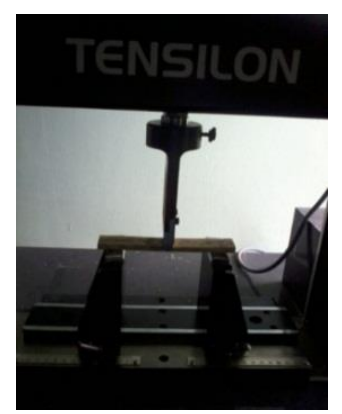

(b)
Gambar 3. (a) uji tarik, (b) uji lentur

\section{METODE PENELITIAN}

Dalam penelitian ini telah dibuat spesimen sampel papan komposit dengan pembuatan volume pencetakan dengan aturan $30 \%$ serat alam dan $70 \%$ matriks PVAc. Seart alam SSK dan SBK dibauat dalam bentuk serbuk atau potongan-potongan kecil seperti yang ditunjukan pada gambar 1. Serat sendiri merupakan campuran antara serat batang pisang (SBP) dengan serat sabut kelapa (SSK).Dalam hal ini dibuat 7 buah sampel dengan komposisi serat sebagai berikut : (A) SBP100\%: SSK0\%, (B) SBP80\%: SSK20\%, (C) SBP $60 \%: \mathrm{SSK} 40 \%$, (D) SBP $40 \%: \mathrm{SSK}$ 60\%, (E) SBP 20\% :SKK 80\%, (F) SBP 0\%: SKK $100 \%$ dan (G) SBP 50\% :SKK $50 \%$.

Cara penentuan volume fraksi serat, maka terlebih dulu perlu diketahui massa jenis matrik PVAc. Massa jenis PVAc setelah dcampur air $10 \%$, di dapat $0,9 \mathrm{gr} / \mathrm{cm}^{3}$. Maka selanjutnya menghitung volume cetakan untuk spesimen sampel papan. Volume cetakan diperoleh $18 \mathrm{~cm}$ x $18 \mathrm{~cm} \mathrm{x} 0,5 \mathrm{~cm}=162 \mathrm{~cm}^{3}$. Jika cetakan tersebut disii seluruhnya dengan matrik, maka dengan menggunakan rumus massa jenis (1), didapat massa yang dibutuhkan $=0,9 \mathrm{gr} / \mathrm{cm}^{3} \mathrm{x}$ $162 \mathrm{~cm}^{3}=145$ gr. Jadi massa total untuk mengisi cetakan tersebut 145 gr. Jika dibutuhkan $70 \%$ matriks dan $30 \%$ serat, berarti massa matrik $70 \%$ x $145 \mathrm{gr}=102$ gr dan untuk massa serat $30 \%$ x $145 \mathrm{gr}=43$ gr. Sedangkan jika serat tersebut merupakan campuran dari 60 $\%$ SSK dan $40 \%$ SBK, maka massa SSK $=60 \%$ x 43 gr $=26$ gr dan massa $\mathrm{SBP}=30 \%$ x $43=$ 17 gr. Perhitungan tersebut sesuai dengan persmaan dari Harper dalam Oroh et al. (2013) yaitu

$$
\begin{gathered}
W_{f}=\frac{w_{f}}{w_{c}}=\frac{\rho_{f} V_{f}}{\rho_{c} V_{f}}=\frac{\rho_{f}}{\rho_{c}} V_{f} . \\
V_{f}=\frac{\rho_{c}}{\rho_{f}} W_{f}=1-V_{m}
\end{gathered}
$$

Setelah sampel dicetak, kemudian di keringkan diabawah sinar matahari ( jika tak hujan) atau di oven dalam suhu $100 \%$ selama 4 kali 30 menit, sudah menunjukkan sampel yang kering. Hasil papan komposit serat alam SSK campur SBP ditunjukan pada gambar 4.

Setelah produk papan selesai dibuat, maka dibuatlah spesimen sampel untuk uji tarik dan uji lentur. Adapun bentuk sepesimen papan komposit untuk uji lentur dan uji tarik ditunjukkan pada Gambar 5.

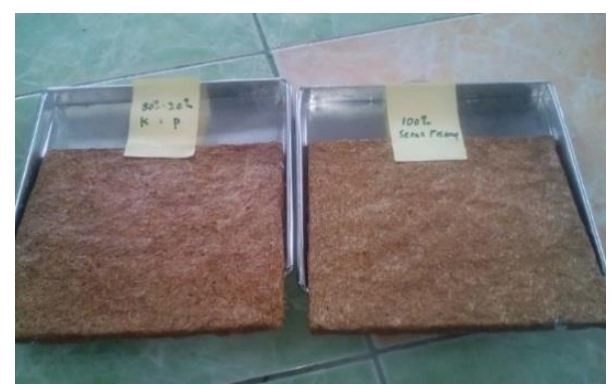

Gambar 4. Produk Papan Komposit

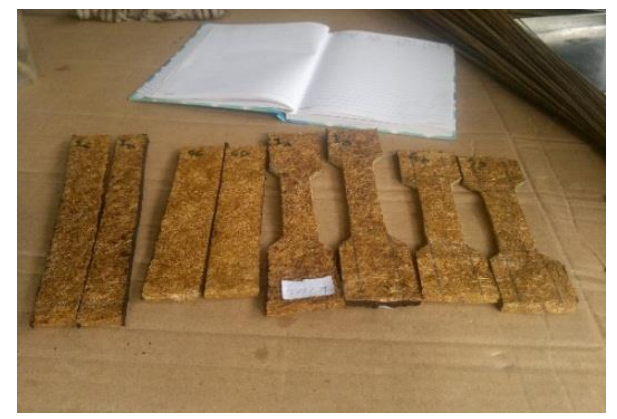

Gambar 5. Spesimen Uji Lentur dan Uji Tarik 


\section{HASIL DAN PEMBAHASAN}

Setiap potongan sampel ditimbang dan diukur panjang, lebar dan tebalnya. Massa jenis ( $\rho)$ dari setiap specimen papan partikel diambil dari nilai rata-rata massa jenis sesuai persamaan (1), (2) dan (3) di atas. Sedangkan untuk mengukur kadar air sampel papan partikel telah dilakukan sesuai persamaan (4) dengan sampel dari setiap specimen. Hasil pengukuran sifat fisika ditampilkan pada Table 2.
Berdasarkan hasil pengukuran spesimen papan komposit untuk variasi campuran pada tabel 2 tersebut menunjukkan karakteristik papan komposit yang memiliki massa jenis berkisar antara $0,5 \mathrm{gr} / \mathrm{cm}^{3}$ sampai $0,75 \mathrm{gr} / \mathrm{cm}^{3}$. Menurut Rahayu \& Widayani ( 2015), papan komposit ini termasuk pada katagori berkerapatan sedang.

Tabel 2. Massa Jenis dan Kadar Air Papan Komposit Serat Alam

\begin{tabular}{|c|c|c|c|c|}
\hline \multicolumn{3}{|c|}{$\begin{array}{c}\text { Sampel spesimen } \\
\text { Serat : Matriks }=30 \%: 70 \%\end{array}$} & \multirow{2}{*}{$\begin{array}{c}\text { Massa jenis }(\rho) \\
\left(\mathrm{gr} / \mathrm{cm}^{3}\right)\end{array}$} & $\begin{array}{c}\text { Kadar Air } \\
(\mathrm{KA})(\%)\end{array}$ \\
\cline { 1 - 2 } Serat & $\%$ SSK & $\%$ SBP & $0,7067 \pm 0,0157$ & 11,1111 \\
\hline A. & 100 & 0 & $0,6386 \pm 0,0126$ & 11,1224 \\
\hline B. & 50 & 50 & $0,5441 \pm 0,0091$ & 13,9610 \\
\hline C. & 80 & 20 & $0,6012 \pm 0,0100$ & 13,3928 \\
\hline D. & 60 & 40 & $0,7497 \pm 0,0136$ & 10,5556 \\
\hline E. & 40 & 60 & $0,6876 \pm 0,0108$ & 13,0268 \\
\hline F. & 20 & 80 & $0,6765 \pm 0,0118$ & 12,9032 \\
\hline G. & 0 & 100 & \multicolumn{2}{c}{} \\
\hline
\end{tabular}

Ini artinya material komposit tersebut benar merupakan papan buatan yang mempunyai massa jenis lebih kecil dari massa jenis air. Dengan kata lain material papan partikel komposit serat SSK dan SBK tersebut jelas mengapung di air.

Jika digambarkan dalam bentuk grafik trend line untuk besaran massa jenisnya ditinjau dari muatan fraksi SSK dapat dilihat pada Gambar 6 berikut ini.

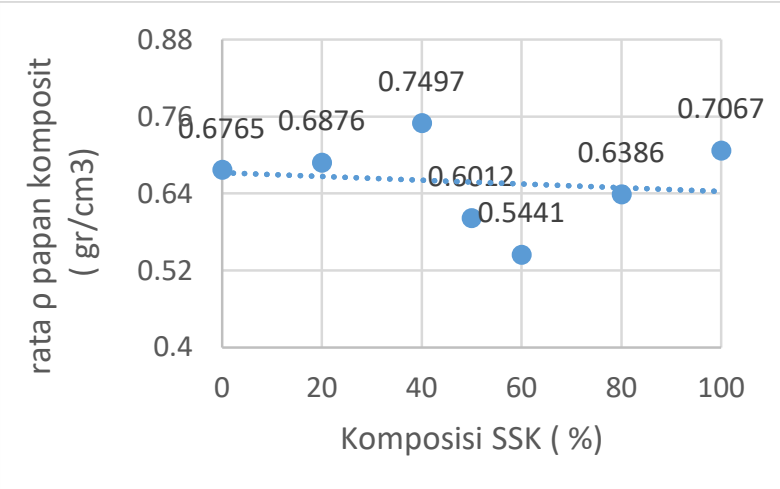

Gambar 6. Trend line Massa jenis muatan SSK
Pada Gambar 6 tersebut menunjukkan bahwa semakin besar muatan SSK dalam campurannya dengan SBP, maka massa jenis campuran serat tersebut cenderung massa jenisnya lebih mengecil. Nilai ektrim ditunjukan dengan perbandingan SSK $40 \%$ dan SBP $60 \%$ massa jenis paling besar yaitu 0.7497 $\mathrm{gr} / \mathrm{cm}^{3}$ dan terendah dengan perbandingan campuran SSK 60\% dan SBP $40 \%$ diperoleh massa jenis $0,5441 \mathrm{gr} / \mathrm{cm}^{3}$. Rerata massa jenis (densitas) papan ini telah memenuhi kriteria SNI 03-02105-2006.

Pengukuran terhadap kadar air dari spesimen tersebut, hasil penimbangan dalam keadaan basah, kemudian di oven selama 60 menit menunjukkan hasil kadar air berkisar antara $10,56 \%$ hingga $13,96 \%$. Secara grafik maka pengaruh variasi campuran terhadap kadar airnya dapat dilihat pada Gambar 7 berikut ini. 


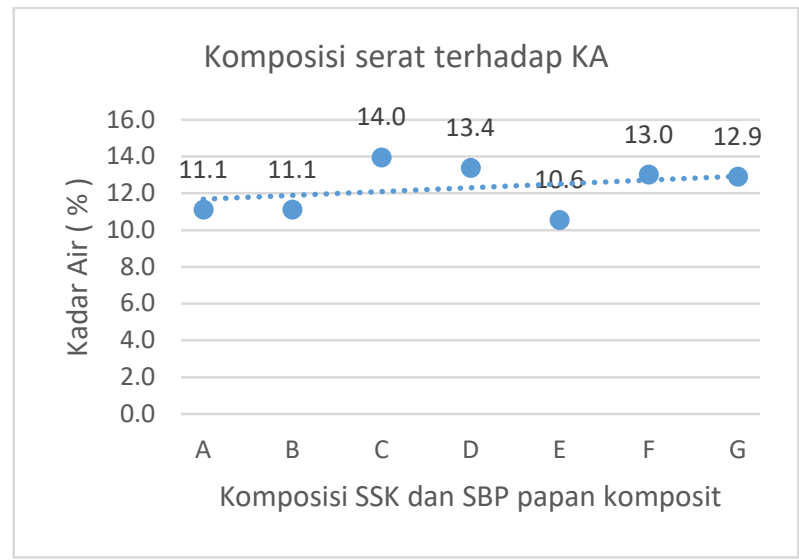

Gambar 7. Kadar Air papan komposit

Berdasarkan gambar 7 diatas, trend line kadar air untuk campuran serat tersebut adalah semakin banyak kandungan SBP terhadap SSK, maka kadar air semakin besar.

Sesuai dengan standar pengukuran uji tarik dan uji bending sebagai sifat mekanik papan komposit digunakan alat yang disebut
tensilon.Sampel uji untuk setiap sampel papan partikel diberikan 2 potong untuk uji tarik dan 2 potong untuk uji bending ( lentur ).

Pada persamaan (6) dalam menghitung MOR hasil uji tarik, faktor yang berpengaruh adalah panjang, tebal dan lebar dari jaws (bagian menjorok ke dalam) pada sampel yang diukur, dimana bagian luas di kedua ujung digunakan untuk memegang sampel.

Sedangkan uji uji lentur sesuai persamaan (9) dalam menghitung MOE, faktor yang berpengaruh pada sampel adalah jarak span (posisi penyangga sampel, ketebalan dan lebar sampel.

Hasil pengukuran dan perhitungan dengan terhadap uji tarik dengan menggunakan persamaan (6) (7) dan (8), begitu juga terhadap uji lentur dengan persamaan (9),(10) dan (11) di tunjukkan pada tabel 3 berikut ini.

Tabel 3. Nilai MOR dan MOE Papan Komposit Serat Alam

\begin{tabular}{|c|c|c|c|c|}
\hline \multicolumn{3}{|c|}{$\begin{array}{c}\text { Sampel spesimen } \\
\text { Serat }: \text { Matriks }=30: 70\end{array}$} & \multirow{2}{*}{$\begin{array}{l}\text { Kuat Tarik } \\
(\mathrm{MOR}) \\
\left(\mathrm{kgf} / \mathrm{cm}^{2}\right)\end{array}$} & \multirow{2}{*}{$\begin{array}{c}\text { Kuat Lentur / bending } \\
\text { (MOE) } \\
\left(\mathrm{kgf} / \mathrm{cm}^{2}\right)\end{array}$} \\
\hline Serat & $\%$ SSK & $\% \mathrm{SBP}$ & & \\
\hline A. & 100 & 0 & $7.472,30 \pm 234,95$ & $17.046,31 \pm 563,86$ \\
\hline B. & 50 & 50 & $3.483,44 \pm 116,09$ & $17.307,21 \pm 573,81$ \\
\hline $\mathrm{C}$. & 80 & 20 & $7.199,53 \pm 186,92$ & $15.981,23 \pm 513,74$ \\
\hline D. & 60 & 40 & $7.180,94 \pm 171,35$ & $17.822,22 \pm 608,06$ \\
\hline E. & 40 & 60 & $7.296,34 \pm 194,43$ & $19.557,05 \pm 702,67$ \\
\hline $\mathrm{F}$. & 20 & 80 & $6.629,05 \pm 248,81$ & $17.821,92 \pm 621,31$ \\
\hline G. & 0 & 100 & $6.583,13 \pm 184,50$ & $27.243,74 \pm 905,12$ \\
\hline
\end{tabular}

Tabel 3 di atas menunjukkan bahwa besarnya nilai MOR untuk keseluruhan sampel berkisar antara 3483,44 kgf/ $\mathrm{cm}^{2}$ - 7472,30 $\mathrm{kgf} / \mathrm{cm}^{2}$. Jika mengacu pada standar SNI pada tabel 1, hal ini dapat diterima, karena nilai MOR minimal yang dikehendaki $80 \mathrm{kgf} / \mathrm{cm}^{2}$. Jadi hasil MOR ini telah memenuhi kriteria SNI03-2105-2006.

Sedangkan untuk uji lentur (MOE) diperoleh dari Tabel 1 tersebut berkisar antara
$15.981,23 \mathrm{kgf} / \mathrm{cm}^{2}-27.243,74 \mathrm{kgf} / \mathrm{cm}^{2}$. Nilai MOE juga apabila mengacu ke SNI di atas telah memenuhi kriteria kualitas dengan nilai minimal yang diterima $15.000 \mathrm{kgf} / \mathrm{cm}^{2}$.

Apabila dibuatkan grafik trendline pengaruh komposisi serat SSK dan SBK, maka akan nampak ada nilai kecenderungan besarnya nilai MOR terhadap komposisi serat.

Hal ini dapat ditunjukkan pada Gambar 8 . 


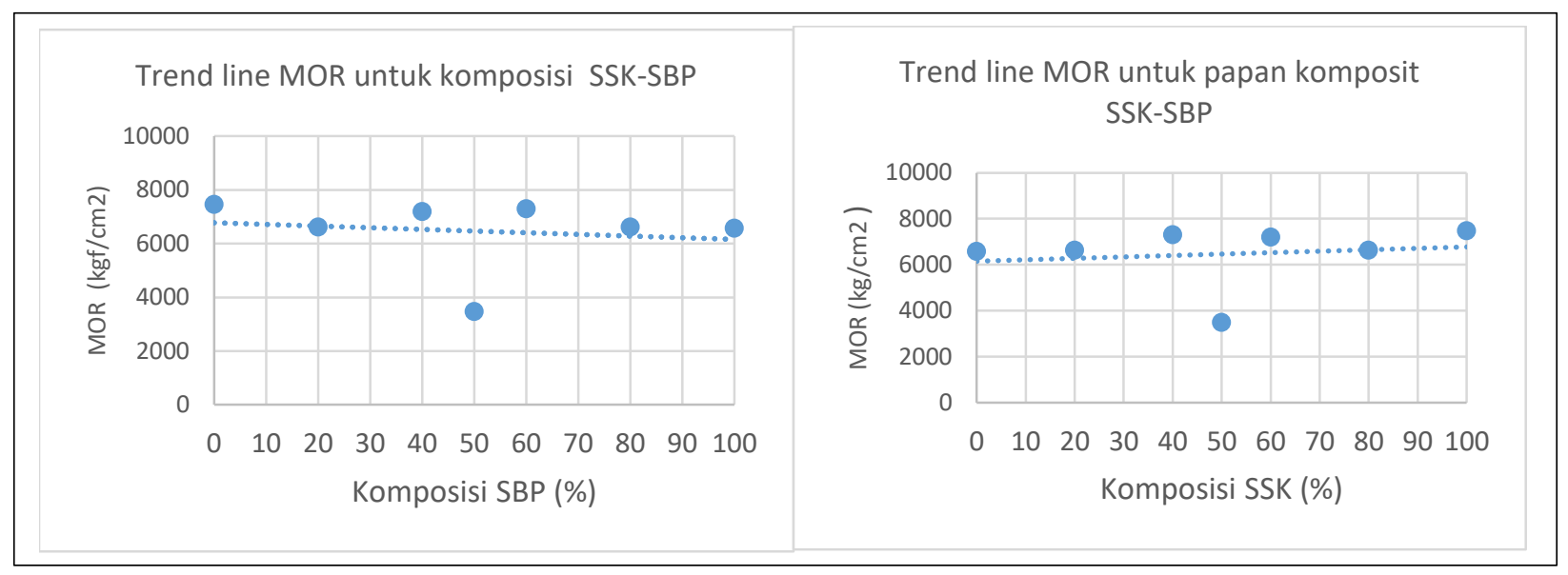

Gambar 8. Trendline MOR terhadap komposisi SSK dan SBP

Pada gambar 8 tersebut menunjukkan adanya pengaruh besarnya komposisi terhadap nilai MOR, terbukti jika komposisi SSK lebih besar dari SBP, cenderung nilai MOR nya meningkat.

Perbedaan yang paling mencolok pada campuran untuk masing-masing serat $50 \%$, nilai MOR nya sangat rendah.
Berdasarkan tabel 3 untuk kasus uji lentur, nilai terendah $\mathrm{MOE}$ terdapat pada komposisi sampuran SSK 80\% dan SBP $20 \%$. Tetapi besarnya campuran serat dapat dilihat trend linenya pada Gambar 9.

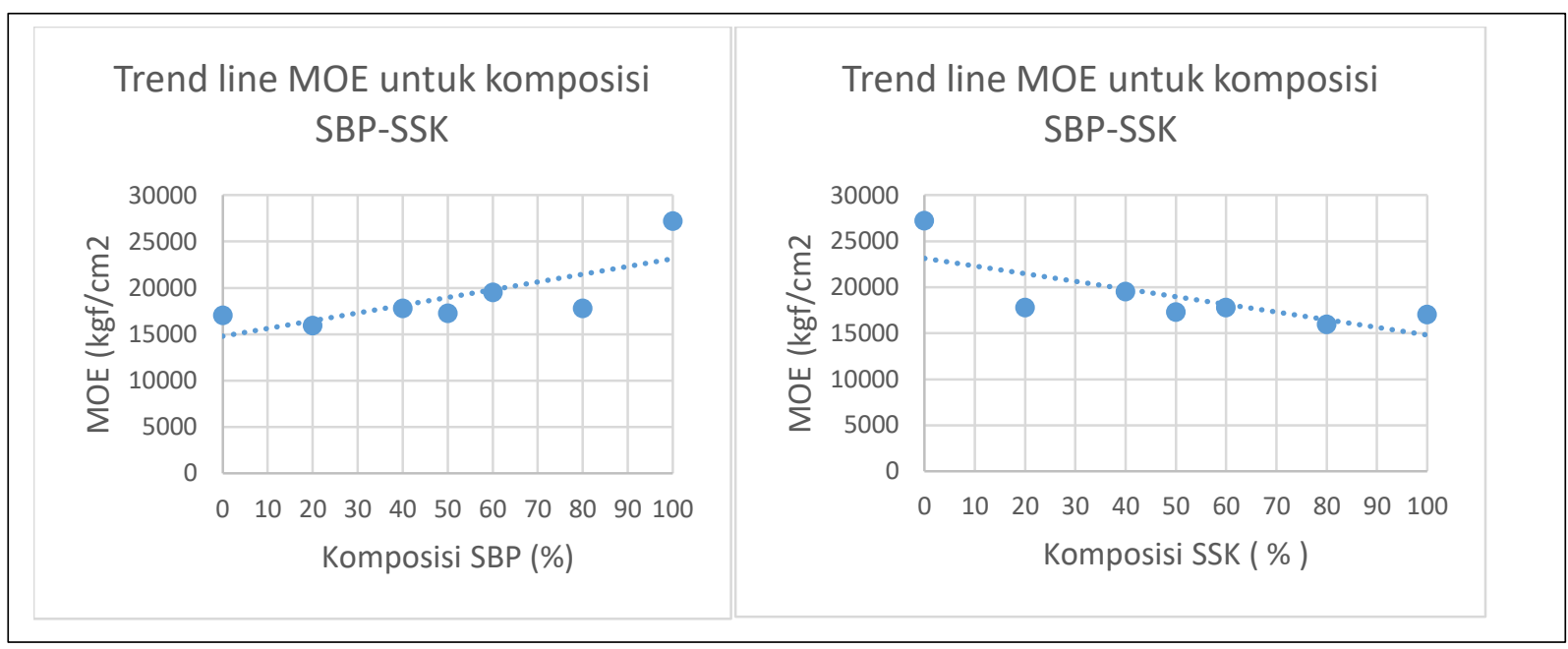

Gambar 9. Trend line MOE terhadap komposisi SBP-SSK

Pada gambar 9 tersebut menggambarkan trendline bahwa semakin besar komposisi SSK terhadap SBP, nilai MOE nya semakin kecil.

Hasil penelitian Khotimah, 2014 menunjukkan bahwa sifat mekanik papan komposit dari serat batang pisang dengan penambahan fraksi volume SBP pada komposit SBP Epoksi berpengaruh pada meningkatnya kekuatan tarik komposit SBP Epoksi, tetapi nilai modulus elastisitasnya menurun. Sedangkan dalam kasus pencampuran serat SBP dan SSK menunjukkan apabila komposisi SBP lebih besar terhadap SSK, maka nilai elastisitasnya malah membesar menurut trendline gambar 9 diatas.

Mengenai besarnya nilai MOR dan MOE untuk berbgai komposit serat alam, ternyata berbeda tergantung pada perlakukan yang 
diberikan. Wibisono (2015), bahwa besarnya nilai MOR dan MOE sangat dipengaruhi oleh suhu ruangan dimana sampel di uji. Dan suhu terbaik untuk mendapatkan nilai elastisitas tertinggi pada suhu sampel ruang uji sampel $35^{\circ} \mathrm{C}$. Sedangkan pengujian yang dilkukan pada papan partikel komposit berbahan dasar serat alam sabut kelapa (SSK) dan serat batang pisang (SBP) dilakukan di ruangan dengan suhu kamar.

Sedangkan pada penelitian Clareyna \& Lizda (2013), besarnya sifat mekanik material komposit dipengaruhi besarnya mesh (serbuk partikel serat komposit). Dalam artikel tersebut disimpulkan bahwa serat penguat berukuran 200 mesh, merupakan sampel terbaik dengan kuat tarik 28,83m MPa dan densitasnya 1,15 $\mathrm{gr} / \mathrm{cm}^{3}$. Sedangkan papan partikel komposit SSK dan SBP dibuat dalam ukuran serat partikel dengan pangjang serat maksimum 1 $\mathrm{cm}$. Peneliti yakin, apabila bentuk serat ini dibuat berukuran serbuk akan mendapatkan sampel papan partikel komposit berbahan dasar serat alam dengan nilai MOR dan MOE yang berrbeda dengan yang dihasilkan dalam penelitian ini.

\section{PENUTUP}

Berdasarkan hasil dan pembahasan yang telah dipaparkan dapat disimpulkan bahwa:

1. Komposisi campuran serat alam sabut kelapa (SSK) dan serat batang pisang (SBK) dengan matriks pada pembuatan papan partikel komposit Poly Vinyl Acetate (PVAc) menunjukkan hasil sifat fisik maupun mekanik yang bervariasi atau tidak ada yang sama untuk masing-masing spesimen sampel. Oleh karena itu dapat dikatakan bahwa Komposisi campuran serat alam sabut kelapa (SSK) dan serat batang pisang (SBK) dengan matriks pada pembuatan papan partikel komposit Poly Vinyl Acetate (PVAc) berpengaruh terhadap nilai sifat fisik maupun mekaniknya.
2. Mengacu pada hasil analisa hasil pengukuran, nilai sifat fisik (densitas dan kadar air) dan sifat mekanik (uji tarik dan uji bending) yang diukur, untuk semua spesimen sampel papan partikel berbahan alam serat sabut kelapa (SSK) dan serat batang Pisang (SBP) dengan matriks perekat lem PVAc berada pada nilai yang sesuai dengan kualitas standar SNI032105-2006.

\section{UCAPAN TERIMAKASIH}

Ucapan terima kasih disampaikan kepada Prodi Pendidikan Fisika dan FKIP Unram, yang telah mendanai penelitian dengan dana PNBP anggaran 2017. Terimakasih pula saya sampaikan kepada administrator Jurnal online Pendidikan Fisika dan Teknolgi FKIP Universitas

\section{REFERENSI}

Budha, et al. 2011. Pengaruh Alkalisasi Komposit Serat Kelapa-Poliester Terhadap Kekuatan Tarik. Jurnal Rekayasa Mesin. 1(2), 123-129.

Bushra, et al. 2010. Study of the mechanical properties for unsaturated Polyester reinforced by natural fibers. Journal of Al-Nahrain University. 13(3), 65-68.

Clareyna, D.C \& Lizda Johar Mawarani. 2013. Pembuatan dan Karakteristik Komposit Poilmer Berpenguat Bagasse. Jurnal Teknik Pomits. 2(2), 208-213.

Ezema, L.C, et al. 2012. Ply Tensile Properties of Banana Stem and Banana Punch Fibers Reinforced Natural Rubber Composite. Nigerian Journal of Technology. 31(1), 25-30.

Khotimah, Khusnul. 2014. Sifat Fisi Komposit Serat batang Pisang sebagai Bahan Penyerap Bunyi. Tesis Magister IPA. Universitas Mataram.

Kartini, R, et al. 2002. Pembuatan dan Karakterisasi Komposit Polimer berpenguat Serat Alam. Jurnal Sains Material Indonesia. 3(3), 30-38. 
Kurniawan, E. 2011. Sifat Fisis Polimer Komposit. Tesis. Universitas Mataram

Maleque, M.A., Belal, F.Y., \& Sapuan S.M. 2007. Mechanical Properties Study of Pseudo-Stem Banana Fiber Reinforced Epoxy Composite. The Arabian Journal for science and Engineering. 32(2B), 359-364.

Masturi, et al. 2010. Efektivitas Polivinil Acetat Sebagai Matriks pada Komposit Sampah. Jurnal Berkala. 13(2), (61-66)

Multazam, M. 2011. Karakterisasi Papan Komposit Enceng Gondok dengan Matriks Poly Vinil Acetat. Tesis. Universitas Mataram

Oroh, J, et al. 2013. Analisis Sifat Mekanik Material Komposit dari Serat Sabut Kelapa. Universitas Sumatra Utara.

Multazam, M. 2011. Karakterisasi Papan Komposit Enceng Gondok dengan Matriks Poly Vinil Acetat. Tesis. Universitas Mataram

Nasmi, H. et al. 2011. Analisa Kekuatan Tarik Komposit Termoplastic Diperkuat Serat Pohon Pisang Dengan Arah Serat Searah. Jurnal Teknik Rekayasa. 12(1),-

Noni, N. 2013. Pengaruh Ketebalan Serat Pelepah Pisang Kepok (Musa Paradisiaca) terhadap Sifat Mekanik Material Komposit Poliester-Serat Alam. Jurnal Fisika Unand. 2(3), 195-203.

Nurrani, L. 2012. Pemanfaatan Batang Pisang (Musa sp.) sebagai Bahan Baku Papan Serat dengan Perlakuan Termo-Mekanis. Jurnal Penelitian Hasil Hutan. 30(1), 19.

Paryanto, D.S., Sari, N.H. \& Putra, D.G.P. 2012. Pengaruh Orientasi dan Fraksi Volume Serat Daun Nanas (Ananas comosus) terhadap Kekuatan Tarik Komposit Polyester Tak Jenuh (UP). Jurnal Dinamika Teknik Mesin, 2(1), 2032.

Rahayu, M. \& Widayani. 2015. Studi Awal Pembuatan Komposit Papan Serar
Berbahan Dasar Ampas Sagu. Prosiding SKF. 16-17 Desember 2017.

Rangkuti, Z. 2011. Pembuatan dan karakterisasi papan partikel Dari campuran resin polyester dan serat kulit jagung. Tesis. Universitas Sumatera Utara.

Sudarsono, et al. 2010. Pembuatan Papan Partikel berbahan baku Sabut Kelapa dengan bahan Pengikat Alami (Lem Kopal). Jurnal Teknologi. 3 (1), (22-32)

Wibisono, (2015). Analisa pengujian Tarik Pipa Komposit Serat Batng Pisang Bermatrik Poliester BQTN 157 Dengan Sudut Serat $65^{\circ}-65^{\circ}$ pada variasi temperature ruang uji. Skripsi. Fak. Teknik. Universitas Muhamadiyah Surakarta. 